\title{
Do disasters trigger protests? A conceptual view and review of the connection between disasters, injustice, and protests - the case of COVID-19
}

\author{
Sara Vestergren ${ }^{1 \dagger^{*}}$, Mete Sefa Uysal ${ }^{2 \dagger}$, and Selin Tekin ${ }^{3 \dagger}$ \\ ${ }^{1}$ School of Psychology, Keele University, Keele, UK \\ ${ }^{2}$ Department of Social Psychology, Friedrich Schiller University Jena, Jena, Germany \\ ${ }^{3}$ School of Psychology \& Neuroscience, University of St Andrews, Fife, UK \\ $\dagger$ These authors have contributed equally to this work and share first authorship \\ *Correspondence: \\ Sara Vestergren \\ s.vestergren@keele.ac.uk
}

Keywords: protest, disaster, COVID-19, pandemic, injustice, inequality

\begin{abstract}
People around the globe were and are affected by the highly contagious virus SARS-CoV-2 (Coronavirus, COVID-19) far beyond the virus itself. Despite the high viral transmission, people did not stop acting collectively. Sometimes these collective actions were against government regulations to health and safety (e.g., anti-lockdown), or to deal with systemic injustice and inequality affecting specific groups (e.g., Black Lives Matter). In this conceptual paper, we discuss the relation between protests and disasters. More specifically we discuss the crucial element of perceived social injustice and inequality for protest to emerge during or in the aftermath of disasters. We review literature related to disasters and protests before moving on to the COVID-19 pandemic to discuss how the context of COVID19 can have influenced protests as well as protests' potential impact on viral transmission. We demonstrate that protests during or in the aftermath of disasters are not uncommon. Furthermore, we suggest a direct link between emergent or increased perceived injustice and inequality and protests during/after disasters.
\end{abstract}

\section{Introduction}

The COVID-19 pandemic, as other disasters previously, forced people to change their everyday lives and made old habits questionable. In disasters and mass-emergencies people are more likely to engage in collective action and cooperative behaviours than to panic and engage in selfish behaviours (e.g., Drury, 2018; Grimm et al., 2014). Similar patterns have been observed during the COVID-19 pandemic, where people join mutual aid groups to help others in their communities with for example dog-walking, shopping, and other things to facilitate reduction in virus transmission (see Fernandes-Jesus et al., 2021; Mao et al., 2021). Research on collective action in the form of cooperation and mutual aid during and after disasters have increased in the last decade, demonstrating that in disasters a shared fate often develops which facilitates for a shared identity to emerge (e.g., Drury et al., 2009a, 2009b). Through shared fate, people come to see themselves as part of the same group or community, which functions as a base for solidarity, cohesion, and empowerment to emerge (Drury and Reicher, 1999, 2009). In their studies of mass-emergencies and disasters, Drury et al. (2009a, 
2009b; for review see Drury, 2018) show how the shared experience create unity as social relations between the victims/survivors are created or amplified. The unity and shared identity that emerges increases both the likelihood of supporting others perceived to belong to the same shared identity, and the expectation of support from other group/community members (Drury et al., 2016). When people act in solidarity, they do not only share a common fate and come together, but they are also empowered to take strategic steps to cope with the disaster. For example, solidarity can reach across group boundaries, and aid in mobilisation. The process of collective empowerment can be achieved with strategic steps, these steps include reaching out to wider groups of supporters who are not directly affected by the disaster (Tekin Güven and Drury, 2020), hence mobilising solidarity and support further. As demonstrated above, it is not uncommon that collective action, in the form of cooperation, emerges during and after disasters (e.g., Aldrich, 2013 Alfadhli and Drury, 2018; Drury et al., 2016; Ntontis et al., 2018, 2020).

Nardulli et al. (2015) argue, based on studies of rapid-onset climate change disasters (e.g., storms and floods), that collective action after disasters can take one more path, in addition to cooperation, the path of conflict. While identifying that capacity to generate solidarity creates cooperation after disasters, Nardulli et al. suggest that fear, scarcity, and uncertainty can create conflict. However, the literature exploring the conflict path in the aftermath of disasters mainly focus on civil war, conflict between an armed large group against the authorities, as a consequence of a disaster (Slettebak, 2013). Additionally, most of the conflict studies focus on the national level, which neglects that disasters can impact smaller areas and collective actions occur locally within nations. What is less known in the 'conflict path' is the connection between disasters and other types of 'conflictual' collective actions, such as local protests, rallies, and demonstrations. In this paper, we synthesise previous research on disasters and collective action (in the form of protests and collective activism) and use the COVID-19 pandemic as a case study to theorise about protests in the aftermath of the pandemic. Before addressing protest in relation to COVID-19 we start by outlining predictors of unrest after disasters and emphasise a few cases where protests have been linked to the aftermath of disasters.

\section{Predictors of political unrest after disasters}

Although Nardulli et al. (2015) identify human threats as predictors of conflict, they emphasise that these alone are not sufficient for conflict to arise. They argue, as seen elsewhere, that there is a plethora of social and societal mechanisms involved in the emergence of conflict. It should also be emphasised that only a small portion of disasters have been related to subsequent conflict. For example, Nardulli et al. (2015) found that only $15 \%$ of storms and floods had resulted in increased intensity in political violence. Using a longitudinal perspective on disasters in India (1956-2002), Slettebak (2013) explored whether disasters had an impact on the likelihood of violent politically motivated collective action. Similar to Nardulli et al. (2015), Slettebak did not find a link between natural disasters and widespread politically motivated violence. Slettebak (2013) explains the findings through a broader discussion suggesting that the likelihood of protests is lower in authoritarian regimes violently suppressing collective actions.

The importance of societal factors, such as a country's ruling system or economical level have been identified as predictors for emergence of unrest after disasters. For example, exploring the risk of violent civil conflict in the aftermath of disasters, Nel and Righarts (2008) found that there was a risk for violent civil conflict both in the short- and mediumterm after a disaster. Earthquakes and volcanic eruptions could introduce a larger risk of 
creating conflict due to their rapid onset (as opposed to slow onset) as well as widespread consequences. Furthermore, they identified that the risk of conflict was increased in countries with high inequality, low or middle income and slow economic growth, as well as if the disaster was earthquake or volcanic eruption. However, due to systemic injustices, even though a country's ruling system is identified as democratic or the country is considered a rich country, unrest can still emerge in relation to disasters (Tierney et al., 2006; Solnit, 2009). The unrest is likely to emerge from the authorities lack of consideration that different groups will have different levels of needs and require varied disaster support for survival before, during, and after a disaster. Hence, the state response and preparation also need to be emphasised in the disaster-conflict relationship. The response of the state has a large impact on whether conflict arises, regardless of whether there are other factors, such as scarcity, that influences the public to challenge authority ( $\mathrm{Nel}$ and Righarts, 2008). The effect of disaster properties as well as societal factors have also been emphasised in more recent models.

Ide et al. (2021) studied flood-related political unrest in Africa, Asia and the Middle East between 2015 and 2018, and identified five intertwined conditions for disaster related political unrest. The first condition is connected to impact in terms of loss of lives, livelihood, or assets etcetera. The second condition is the area's economic development (GDP). GDP affects, for example, whether people have the privilege to move to less disaster-prone areas, as well as their ability to prepare for disasters. Restrictions in mobility and preparation can lead to frustration which in turn elicits political unrest (Ide et al., 2021). Furthermore, Koren et al. (2021) argues, in a study on climate disaster in Kenya, that in cases where both food and water insecurity occur, reinforcing each other, so does social unrest. Ide et als'. (2021) third condition is linked to the size of population. The impact in densely populated communities is greater. Additionally, large population areas are more likely to be heterogeneous, which increases the likelihood of some people being in opposition to the state as well as having time to protest. Relatedly, the fourth condition, democratic system, can have an impact through leadership as well as repression. Ide et al. (2021) suggest that in democratic societies where the risk of repressive consequences is lower, along with the likelihood of responsive leaders/authorities, the risk of protests might be higher compared to repressive autocratic societies. Conversely, they also emphasise that the government's response to the disaster, such as repressive measures, can be a factor in eliciting political unrest. The last condition relates to societal inequality and exclusion and refers to certain groups being excluded from the political power (ethnopolitical exclusion), and less likely to receive support before and after disasters. Taken together, societal factors often overweigh the disaster properties in relation to risk of unrest in the aftermath of disasters. Importantly, the above-mentioned studies focus on a widespread civil conflict or unrest and neglect the more common type of conflict/collective action such as protest marches or rallies. In the next section we will outline some examples of disasters that have elicited national and local protests activities, after addressing the social psychological framework for collective action emergence.

\section{Cases of protest linked to previous disasters}

Social psychological models identify three key psychological antecedents for participating in protests. First, a sense of shared identity, an identification with a relevant group, predicts collective action participation (e.g., Drury and Reicher, 2000; Tajfel and Turner, 1979; van Zomeren et al., 2008). The shared identification could for example be as a minority community member, a woman, a union member, or an environmentalist. Second, perceived collective injustice, illegitimacy and collective anger as a result of inequalities, predict 
engagement in collective action (e.g., Becker et al., 2011; Drury and Reicher, 2005; Runciman, 1966; Walker and Smith, 2002; van Zomeren et al., 2008). The perceived collective injustice can be in relation to one's own group, or in solidarity with another group (e.g., Subašić et al., 2008). Last, collective efficacy beliefs, a sense of control, agency, strength, and collective effectiveness to challenge the existing power relations predict participation in collective action (e.g., Blackwood and Louis, 2012; Klandermans, 1984; van Zomeren et al., 2004). We argue that disasters can offset or increase already existing perceived group-based injustice (e.g., Templeton et al., 2020), create a shared social identity (e.g., Drury et al., 2009a,b), as well create or increase perceived collective efficacy through a perception that 'we' can be effectful in toppling the power or changing power relations (e.g., changing policy around cladding, increasing transparency in state communication, or shifting the political governance).

Most protests, both disaster-related and others, regardless of the cause or concern, have a focus on fighting perceived societal injustice or inequality, seeking justice or truth. For example, after the horrific events at the Hillsborough stadium where 96 people lost their lives the victims' families were campaigning to seek truth and justice for the victims (Cronin, 2017). For 27 years the fans were blamed for causing the crush, before it was acknowledged that the police had lied and kept pushing the lie.

On the $11^{\text {th }}$ March 2004, four bombs went off on trains in Madrid, killing 192 people and leaving many others injured (Flesher Fominaya, 2011). After the disaster, the government was quick to blame ETA (Euskadi Ta Askatasuna) even though there was information pointing elsewhere. On the $14^{\text {th }}$ March 2004, Spain was about to have its political election. The day before the election, protests and flash mobs named M-13 by the activists occurred. These protests were mainly fuelled by the perception that the government, still blaming ETA, was withholding the truth about the bombings, and were involved in a media blackout (Flesher Fominaya, 2011). Activists protested in front of the ruling party's headquarter in Madrid, and quickly grew to become 3000-5000 in the crowd. Later that night, similar protests emerged in other cities across Spain. Whether or not related to the protests against the government coverup - it was later proved that the bomb attacks were executed by AlQaeda - the opposition party won unexpectedly, and the voter turnout was extraordinarily high. These protests were kept alive, by mainly young people, for several years, organising protests and flash mobs under the name of 15-M protesting austerity (Flesher Fominaya, 2011).

After the Hurricane Katrina disaster, in and around the city of New Orleans in the US, in August 2005, several grassroot movements and social movements emerged along with strengthening of already existing movements. These movements were mainly focusing on creating a community, while emphasising the inequalities, injustice and restrictions to human rights (Luft, 2009). The relation between systemic injustice and disaster was particularly clear in Hurricane Katrina. Poorer areas, with a majority Black population, were affected more during the disaster than richer (Whiter) areas. Additionally, while people with more financial funds could both prepare for and acquire disaster support, the authorities responded very late with disaster support and relief to the poorer areas. The late response, led to people having to find resources and materials to survive where available, for example from shops, which in turn led to them being described as looters and criminals by some media outlets (Tierney et al., 2006; Solnit, 2009). For at least two years after Hurricane Katrina there were protests, against social injustice, on Gretna Bridge - where the police stopped people from evacuating the disaster area (Heldman, 2010). Furthermore, The People's Hurricane Relief 
Fund organised a demonstration in December 2005 with a focus on human rights and the right to return (Luft, 2009).

The Bangkok floods of 2011 in Thailand was a slow onset disaster - the government had a period of about three months to spend on disaster management and preparation (Marks et al., 2020). The government decided to protect the inner city by building floodwalls, resulting in outer areas of the city being worse off than if the water had been allowed to flow freely (Marks et al., 2020). In the case of the Bangkok floods, there was, as with Hurrican Katrina, a clear difference in the government's treatment of the rich (inner city) and poor (outer city) areas, demonstrating flood injustice and societal inequality. Based on the injustice, nonviolent protests emerged from about 20 communities outside the floodwall (Marks et al., 2020). The protesters demanded that the government should see and treat them as citizens of Bangkok too and started to question the right of defining justice.

In 2011 an earthquake-triggered tsunami caused a shut-down of the cooling systems at Fukushima nuclear plants in Japan, causing a meltdown in three of the plant's six reactors. The tsunami killed 20000 people (Ikegami, 2012) and devastated coastal towns, shut down business and communication (Funabashi and Kitazawa, 2021). On the backend of this, the Fukushima meltdown caused more than 300000 people to be evacuated, and many of them faced not being able to return home for a very long time (Aldrich, 2013). There was already an existing anti-nuclear movement in Japan, however, the disaster prompted more people to question the lack of peoples' influence on policy. The disaster mobilised further support for the anti-nuclear movement while also creating an emerging movement where citizens started measuring the radiation on their own devices as well as organising marches and protests outside the PM's home and the national parliament (Aldrich, 2013; Ikegami, 2012). The mobilisation of the anti-nuclear movement and people's science movement stemmed from discontent with the government's handling of the disaster, lack of transparency, misinformation and supressing both information and data (Aldrich, 2013; Ikegami, 2012). Hence, once again it was not the disaster itself that caused the protests but rather the government's handling of the disaster along with spreading lies and misinformation.

In June 2017 a fire broke out in the Grenfell Tower block in West London, UK. Along with building a community and support, campaigners started protest campaigns in the aftermath of the disaster to challenge negative stereotypes and injustice through government inaction (Tekin Güven and Drury, 2020, 2021). The Grenfell community campaigners self-organized and engaged in non-violent protest activities such as petitions and regular silent walks, still ongoing to seek justice while this paper is written.

Apart from the connection to disasters, the protest and collective action events described above have in common the feature of social injustice and inequality, and state inaction and mistrust. They have a narrative of group-based injustice, distinct outgroups (indicating shared identity) as well as shared social group membership as victims or survivors. Hence, it is not the disaster itself that mobilises various protest movements - it is the lack of preparation, response and management from the authorities and other state actors that provide a platform for the three key predictors (shared identity, group-based injustice, collective efficacy) of collective action to emerge or accelerate. Based on what we know from previous disasters and research on collective action, how can understand the protests during the global COVID19 pandemic? In the next section, we will discuss a few of the protest events occurring during COVID-19.

\section{Protests during the COVID-19 pandemic}


As demonstrated above, protests during or in the aftermath of disasters is not uncommon and has a direct link to emergent or increased social injustice as a result of the disaster. The COVID-19 pandemic has like other disasters disproportionately affected already marginalised communities (see Templeton et al., 2020). At the beginning of the pandemic, a decrease in protests could be observed around the world. However, during 2020 the total number of protests increased by 3\% compared to 2019 (Kishi et al., 2021). Furthermore, compared to 2019, 2020 saw an increase in peaceful protests, and a decrease in the number of protests met with authority intervention as well as a decrease in the number of fatalities related to protests (Kishi et al., 2021).

During the pandemic, several areas of protest causes were observed. We will use two movements to discuss the protests during the pandemic; Black Lives Matter (BLM) and antigovernmental measures enforced to decrease viral transmission (e.g., anti-lockdown). For example, BLM protests ${ }^{1}$ have been a recurring feature worldwide during the pandemic, similarly, anti-lockdown protests have been reported from various areas around the globe such as Italy ${ }^{2}$, Germany and France ${ }^{3}$, and the US ${ }^{4}$ to name a few. At the core of both these protest movements is the perception of protesting perceived injustice in relation to human rights. It is important to emphasise that social injustices and inequalities have increased or been made more visible through the COVID-19 pandemic (Iacoella et al., 2021; Templeton et al., 2020).

The worldwide BLM protests, after the killing of George Floyd (May 25 $5^{\text {th }} 2020$ ), coincided with the early stages of global outbreak and enforcement of national measures to try to manage the transmission of the corona virus (SARS-CoV-2). During the week after the killing of George Floyd more than 8700 protests were recorded across 74 countries (Kishi and Jones, 2020). In total in the US, over 10600 protests were recorded between $24^{\text {th }}$ May and $22^{\text {nd }}$ August 2020 (Kishi and Jones, 2020). In line with general patterns of protest, more than $90 \%$ of the protests were peaceful (Kishi and Jones, 2020). In America, 11 Americans were killed while participating in political protests, 9 of these were from BLM and 2 from pro-Trump protests, and an additional 14 were killed in related events (Beckett, 2020).

In the light of a global pandemic, the big questions are; why did people risk getting infected and spread the virus and did the protests increase viral transmission? The legitimacy of the protests during the pandemic became the subject of heated discussions. On the one hand, the protests were described as events that accelerated the spread of the coronavirus and were discussed as a public health threat. On the other hand, governments and state actors (e.g., police) were accused of attacking the right to protest by using lockdowns and pandemic measures as excuses to clamp down on protesters.

The global spread of the virus with accompanying measures to reduce viral transmission put public health and public welfare (societal inequality) at odds. The restrictions to reduce viral spread affected people's freedom of movement, assembly, and expression. 'New' legislation to protect public health also provided authorities with more ground to strike down on protests (Kampmark, 2020). For example, in the UK during the early stages of the pandemic (until the end of May 2020) assemblies outdoors of more than three people were unlawful, it was later

\footnotetext{
${ }^{1} \mathrm{https}: / /$ www.cntraveler.com/gallery/black-lives-matter-protests-around-the-world

${ }^{2}$ https://www.bbc.co.uk/news/world-europe-54701042

${ }^{3} \mathrm{https}$ //www.theguardian.com/world/2020/nov/02/latest-coronavirus-lockdowns-spark-protests-across-europe

${ }^{4}$ https://www.bbc.co.uk/news/av/world-us-canada-52344540
} 
changed to allowing six people to gather (Kampmark, 2020). Similarly, in New South Wales, Australia, police tried to block demonstrations demanding justice for the deaths of indigenous people in custody. Police threatened potential protesters with fines for breaching health orders, based on the arguments (with no evidence) that BLM protests had led to high infection rates (Kontominas, 2020). Drawing on the restrictions in mobility allowing only 'essential activity' police in both the US (NCAC, 2020) and Australia (O'Sullivan, 2020) dispersed or fined protesters even though they were socially distancing (e.g., being inside their cars). The added public health legislation might also be a factor in police use of force during protests. In 2020 the US authorities intervened in $9 \%$ of all protests, compared to $2 \%$ in 2019 (Kishi and Jones, 2020). It should also be noted that authorities intervened in 9\% of all BLM protests in the US, compared to $2 \%$ for other protests, with $5 \%$ of BLM protests being met with force compared to less than 1\% for other protests (Kishi and Jones, 2020). This disproportionality, in turn, can further fuel the perception of inequality and societal and racial injustice.

One strong driver of the argument that protests increased viral transmission (without evidence) was the media. For example, the Herald Sun (Australia) blamed the BLM protests for the spike in infections (Tavan, 2020). When it was later shown that there were no new infections related to the protests the accusation changed to the argument that protests encouraged people to come out of their homes - argued to spread the virus (it was later shown that the spike was related to companies failing to report positive cases within employee groups) (Tavan, 2020). Conversely, there have been arguments that not protesting societal inequality and racial injustice can be an even larger public health risk than the COVID-19 pandemic and therefore the protests need to continue even in the context of the pandemic (see Kampmark, 2020; Langton, 2020; Ramsden, 2020). Others take a more nuanced route by arguing that protests should be facilitated, in ways that makes pro-health behaviours possible (O'Sullivan, 2020). One clear indication of the extent of the argument that protests are needed even during a pandemic, is the number of articles focusing on staying safe while protesting (see e.g., Aubrey and Gomez Sarmiento, 2020; Russo, 2020). The existence of these articles could be understood as some issues need to be continued and emphasised even through periods of global disasters - one disaster does not make another go away. The protective measures suggested in guides for safe protesting during COVID-19 are described as being outdoors, wearing masks, keeping social distance, and keeping up proper hand hygiene (Aubrey and Gomez Sarmiento, 2020) - hence the same measures as in all other contexts. There were also reports of protesters urging other protesters to get tested after participation (Russo, 2020). Despite the increased police powers and the widespread media accusations that protests were potential 'super spreaders' why did people protest during COVID-19?

\section{How did COVID-19 cause protests?}

People will take collective action and participate in protests for causes that resonate with their values and worldview. Choma et al. (2021) surveyed people across the political (and ideological) spectrum and found that participants less supportive of protective measures and compliance in relation to the COVID-19 pandemic scored high on Right Wing Authoritarianism (RWA) and Social Dominance Orientation (SDO), but neither RWA nor SDO predicted collective action. However, scoring high on empathy and group-efficacy predicted collective action tendencies. Rather than focusing on political and ideological dimensions, Bartusevičius et al. (2021) explored the association between the psychological burden of COVID-19 and several dimensions of political unrest in the US, Denmark, Italy 
and Hungary. They found that the psychological burden from COVID-19 was associated with antisystemic attitudes and intentions for both non-violent political activism and intentions to engage in political violence. Bartusevičius et al. (2021) also found an association between self-reported use of violence during BLM protests and counter protests and COVID-19 burden in the US. However, neither political, ideological, nor burden dimensions are likely to make someone protest on its own. It could be suggested that for protest to emerge in relation to the above dimensions there also need to be an exposure and opportunity to protest.

With global lockdowns and stay at home restrictions, people had more time to spend on social media (e.g., Grant and Smith, 2021). The increased time on social media increased the exposure to messages highlighting social inequalities (Grant and Smith, 2021; Ramsden, 2020). The exposure to social inequalities via social media during the pandemic might increase people's sense of perceived injustice and illegitimacy, in turn, collective anger. Importantly, protests are useful in raising awareness (e.g., Bugden, 2020) as well as mobilising and motivating people in other places to take similar action (e.g., Drury et al., 2020), providing an opportunity for more people to get involved (Ramsden, 2020). Seeing others take action, or when there is a perception of many taking action has an impact on the perceived collective efficacy (e.g., Haugestad et al., 2021). Furthermore, the more people that join, the more inclusive the shared category gets, which allows for more people to identify with the group and the causes (Louis et al., 2016). Hence, some elements of the pandemic might have allowed for increased mobilisation and collective action activity through exposure to the common predictors of collective action (see e.g., Van Zomeren et al., 2008).

Consequently, the increased frustration and perception of injustice, and sense of a shared identity through shared struggle, along with the sense that we can challenge the existing power relations (e.g., authorities) can increase the likelihood of people taking collective action and joining protests, even during a global pandemic.

The pandemic exposed already existing unequal societal systems, and increased inequalities further in already marginalised communities (Templeton et al., 2020). Iacoella et al. (2021) argues that in the US, counties with existing high inequality were more likely to experience protests in relation to negative consequences of the pandemic. Marginalised communities are often characterised by an existing lack of trust in governmental measures (see Murphy and Cherney, 2017; Williams, 1998). Additionally, enforcement of strict pandemic measures, leading to increase in protest, hit marginalised communities hardest as they are less likely to have financial and social buffers, hence restrictions limit their access to basic survival means (Iacoella et al., 2021). People that had lost their jobs or had other financial issues because of the pandemic were more likely to participate in the BLM protests, through a wider framework of opposing inequality and police brutality (Arora, 2020). Furthermore, of their surveyed participants, Arora (2020) found that $52 \%$ had been affected negatively financially by the pandemic. In terms of ethnicity, $69 \%$ of black participants, compared to $46 \%$ of white participants, reported financial hardship caused by the pandemic. Although all participants agreed with the wider cause of the protests (i.e., racial injustice), Arora (2020) emphasised that the pandemic was the factor that made them take to the streets.

To sum up, inaction and failures by governments to manage the pandemic have functioned to increase existing social injustice, thereby fuelling protests (Kishi et al., 2021). In the next, and final section, we address the common critique directed toward protests during the pandemic - the argument of protests as 'super-spreaders'.

\section{Protests and Virus Spread}


During the pandemic protests around the world, such as BLM protests in the US, farmer resistance in India, protests against violence towards women in the UK, and Boğaziçi resistance in Turkey were subject to heavy-handed policing or police brutality, justified by citing COVID-19 pandemic and health measures (e.g., Stott et al., 2021). However, when focusing on the evidence for viral transmission during protests, the picture becomes different to that painted by state actors, media and opposers to the protest causes (e.g., Kampmark, 2020).

In relation to the BLM protests, it has been argued that there is no clear evidence of a protestrelated increase in the transmission of the coronavirus (Berger, 2020). There have even been suggestions that the large BLM protests resulted in a decrease in viral transmission (e.g., Dave et al., 2021a). The lack of viral transmission during protests has been related to for example protests being held outdoors, often in sunny weather, and in a context where most people were wearing masks and physically moving (Berger, 2020). Using cell-phone data and coronavirus data to assess the viral transmission in relation to BLM protests in large cities in the US, Dave et al. (2021a) suggests that the viral transmission and the growth of the virus, for 35 days post-protests (measured in 242 cities), decreased. They explain the decrease though protesters mainly adhering to mask-wearing and socially distancing coupled with expected behaviours the protesters would have engaged in if not protesting (e.g., meeting up in restaurants or other indoor areas etc.). In cities where there were large protests, indoor venues (e.g., restaurants and smaller shops) closed, and locals not involved in the protests stayed at home rather than going about with their normal day-to-day behaviours which would have been riskier in terms of viral spread. Furthermore, Dave et al. (2021a) noted that in the surrounding areas of the cities with protests, there were no increase in the viral spread hence, the BLM protest, as well as other protests with similar features, cannot be considered as super-spreader events, or even spreader events.

However, some protests (or collective events) have been found to increase viral transmission. Anti-lockdown protests in Germany ('hygiene demo') increased the viral transmission across the protesters' residential areas post-protests (Lange and Monscheure, 2021). Lange and Monscheuer (2021) explain the increase in viral transmission through the protesters (e.g., COVID-deniers) being less likely to adhere to protective health measures. Similarly, in midAugust 2020, about 500000 motorcycle enthusiasts gathered in Sturgis, South Dakota, US for a motorcycle rally. Dave et al. (2021b) found that the event was mainly characterised by non-mask wearing and non-adherence to other protective guidelines, as well as a general opposition to the pandemic "we're being human once again. Fuck that covid-shit" (p. 770). Through cell-phone data, Dave et al. (2021b) found that indoor venues such as restaurants in the area had an increase in customers by $30-90 \%$. In the month following the rally, viral transmission and positive COVID-19 cases increased substantially in the counties with large numbers of rally participants.

How can we explain how some protests become 'super-spreaders' while others reduce viral transmission? A key difference between the events described above (BLM, 'hygiene demo' and the Sturgis rally) is the behavioural norms within the groups. During the BLM protests, most participants were wearing masks and socially distanced (Berger, 2020; Dave et al., 2021). Conversely, during the German anti-lockdown protest as well as the Sturgis rally, the crowd was mainly characterised by opposition to COVID-measures, as well as lack of mask wearing and social distancing (Dave et al., 2021b; Lange and Monscheure, 2021). In crowd events such as protests and rallies a shared social identity often emerges (e.g., Reicher, 1984). The social identity, shared with other protest participants, provides us with definitions of 
possible and appropriate conduct, and enables people to act collectively in normative ways according to ingroup norms (see Drury and Reicher, 2000; Neville et al., 2021). When a social identity is salient, people will view themselves as a member of that group identity and act according to the identity norms and values. Hence, if part of your social identity is to oppose COVID-restriction, or deny the very existence of COVID-19, then you are less likely to take protective measures while in the protest context of anti-lockdown measures. Conversely, if part of your identity is to protect vulnerable or minoritised people/populations such as the BLM protests (or climate protests which are also characterised by protective measures ${ }^{5,6,7}$ ), then you may be more likely to wear a mask and keep social distance during the protest. Importantly, based on the studies provided above, although still very limited in numbers, and the social identity framework of protest participation (see e.g., Drury and Reicher, 2000; Vestergren et al., 2019) we argue that protests with norms of protective behaviours (e.g., mask wearing and social distancing) are unlikely to become 'superspreader' events, or even spreader events. However, if a group norm is to oppose all COVID19 protective measures, then the protest has a great potential to contribute to widespread viral transmission due to participants acting according to the group norms.

Consequently, protests in themselves should not be seen as 'super-spreaders' - contextual factors and the salient social identity (with ingroup values and norms that guide behaviour) determine whether a protest increases or decreases the spread of the coronavirus.

\section{Conclusion}

Disasters, such as the COVID-19 pandemic, often create, or accelerate, the predictors of collective action participation. Perceived collective injustice is often in relation to state actors' inability to prepare, manage and respond to the disaster, and spreading misinformation. As disasters often have the prerequisites for collective action participation maybe the question that should be asked next is 'why do protests not occur after disasters?'. One potential factor to the lack of, or lack of research and reporting on, disaster-related protests could be the need to prioritise the cooperation route (see e.g., Drury et al., 2009a,b) to ensure one self's and others' survival in the aftermath of disasters.

Slettebak (2013) notes that a storm (or other mass-event) is only a storm until it has human consequences/costs, then it becomes a disaster. We would argue, based on previous research, that for the 'storm' to become a disaster, it often needs to have a disastrous preparation and response from state actors, leading to the human costs. The state response, or lack thereof, to the disaster can in turn mobilise protests. The political dimension of disasters has also been noted in relation to the COVID-19 pandemic. The pandemic has become highly politicised, as well as changed patterns for protests around the globe (Kishi and Jones, 2020). Through exposing and accelerating social inequalities, the pandemic offered more opportunities to exposure and mobilisation to movements. Even though it has been widely argued that protests are 'super-spreaders', this argument cannot be generalised to all protests. We suggest that the shared social identity in the crowd, with accompanying values and behavioural norms, is a large factor in whether a protest becomes a 'super-spreader'.

To sum up, disaster-related protest follows the same pattern of predictors as non-disaster protests, however disasters are likely to accelerate and amplify those predictors through state

\footnotetext{
${ }^{5}$ https:/grist.org/climate/despite-Covid-19-young-people-resume-global-climate-strikes/

${ }^{6} \mathrm{https} / /$ www.dw.com/en/coronavirus-fridays-for-future-fff-Covid-19-pandemic-climate-strike/a-56911641

${ }^{7} \mathrm{https} / /$ www.france24.com/en/20200925-masks-up-emissions-down-as-climate-demos-restart
} 
inaction. There is a need for research to focus on the relation between protests and disaster, as protests are a way of raising voice against systemic injustices emerged or increased in the case of an emergency or disaster. Furthermore, protestors or people and their actions affected by the disasters are often blamed or criminalised, delegitimising their aims and actions, for example by blaming them for virus spread or portraying them as looters. Future research should focus on how these systemic injustices occur and how people take an action to fight them or survive in an unjust system amplified by poorly managed disasters. For example, focus on the kind of strategies people use for public safety and seeking justice.

\section{Reference list:}

Aldrich, D. (2013). Rethinking civil society-state relations in Japan after the Fukushima accident. Polity, 45, 249-269. https://doi.org/10.1057/pol.2013.2

Alfadhli, K., and Drury, J. (2018). The role of shared social identity in mutual support among refugees of conflict: An ethnographic study of Syrian refugees in Jordan. Journal of Community \& Applied Psychology, 28(3), 142-155. https://doi.org/10.1002/casp.2346

Arora, M. (2020, August 5). How the coronavirus pandemic helped the Floyd protests become the biggest in U.S. history. The Washington Post.

https://www.washingtonpost.com/politics/2020/08/05/how-coronavirus-pandemichelped-floyd-protests-become-biggest-us-history/

Aubrey, A., and Gomez Sarmiento, I. (2020, June 5). Coronavirus FAQs: How to stay safe while protesting, when you go out after recovery. $N P R$.

https://www.npr.org/sections/goatsandsoda/2020/06/05/870306050/coronavirus-faqshow-to-stay-safe-while-protesting-when-to-go-out-after-recovery

Bartusevičius, H., Bor, A., Jorgensen, F., and Petersen, M. B. (2021). The psychological burden of the COVID-19 pandemic is associated with anti-systemic attitudes and political violence. Psychological Science. Advance online publication.

https://doi.org/10.1177/09567976211031847

Becker, J., Tausch, N., and Wagner, U. (2011). Emotional consequences of collective action participation: Differentiating self-directed and outgroup-directed emotions. Personality and Social Psychology Bulletin, 37, 1587-1598.

https://doi.org/10.1177/0146167211414145

Beckett, L. (2020, October 31). At least 25 Americans were killed during protests and political unrest in 2020. The Guardian.

https://www.theguardian.com/world/2020/oct/31/americans-killed-protests-politicalunrest-acled

Berger, M. (2020, July 8). Why the Black Lives Matter protests didn't contribute to the COVID-19 surge. Healthline. https://www.healthline.com/health-news/black-livesmatter-protests-didnt-contribute-to-covid19-surge 
Blackwood, L., and Louis, W. (2012). If it matters for the group then it matters to me: Collective action outcomes for seasoned activists. British Journal of Social Psychology, 51, 72-92. https://doi.org/10.1111/j.2044-8309.2010.02001.x

Bugden, D. (2020). Does climate protest work? Partisanship, protest, and sentiment pools. Socius: Sociological Research for a Dynamic World, 6, 1-13. https://doi.org/10.1177\%2F2378023120925949

Choma, B., Hodson, G., Sumantry, D., Hanoch, Y., and Gummerum, M. (2021). Ideological and psychological predictors of COVID-19-related collective action, opinions, and health compliance across three nations. Journal of Social and Political Psychology, 9(1), 123-143. https://doi.org/10.5964/jspp.5585

Cronin, M. (2017). Loss, protests, and heritage: Liverpool FC and Hillsborough. The International Journal of the History of Sport, 34(3-4), 251-265. https://doi.org/10.1080/09523367.2017.1369965

Dave, D., Friedson, A., Matsuzawa, K., Sabia, J., and Safford, S. (2021a). Black Lives Matter protests and risk avoidance: the case of civil unrest during a pandemic. National Bureau of Economic Research, Working paper 27408. http://www.nber.org/papers/w27408

Dave, D., McNichols, D., and Sabia, J. (2021b). The contagion externality of a superspreading event: the Sturgis motorcycle rally and COVID-19. Southern Economic Journal, 87(3), 769-807. https://doi.org/10.1002/soej.12475

Drury, J. (2018). The role of social identity processes in mass emergency behaviour: an integrative review. European Review of Social Psychology, 29(1), 38-81. https://doi.org/10.1080/10463283.2018.1471948

Drury, J., and Reicher, S. (1999). The intergroup dynamics of collective empowerment: substantiating the social identity model of crowd behaviour. Group Processes \& Intergroup Relations, 2(4), 381-402. https://doi.org/10.1177/1368430299024005

Drury, J., and Reicher, S. (2000). Collective action and psychological change: The emergence of new social identities. British Journal of Social Psychology, 39, 579-604. https://doi.org/10.1348/014466600164642

Drury, J., and Reicher, S. (2005). Explaining enduring empowerment: A comparative study of collective action and psychological outcomes. European Journal of Social Psychology, 35, 35-58. https://doi.org/10.1002/ejsp.231

Drury, J., and Reicher, S. (2009). Collective psychological empowerment as a model of social change: Researching crowds and power. Journal of Social Issues, 65, 707-725. https://doi.org/10.1111/j.1540-4560.2009.01622.x

Drury, J., Brown, R., González, R., and Miranda, D. (2016). Emergent social identity and observing social support predict social support provided by survivors in a disaster: Solidarity in the 2010 Chile earthquake. European Journal of Social Psychology, 46(2), 209-223. http://dx.doi.org/10.1002/ejsp.2146 
Drury, J., Cocking, C., and Reicher, S. (2009a). Everyone for themselves? A comparative study of crowd solidarity among emergency survivors. British Journal of Social Psychology, 48, 487-506. https://doi.org/10.1348/014466608X357893

Drury, J., Cocking, C., and Reicher, S. (2009b). The nature of collective resilience: survivor reactions to the 2005 London bombings. International Journal of Mass Emergencies and Disasters, 27(1), 66-95. http://www.ijmed.org/articles/113/

Drury, J., Brown, R., González, R., and Miranda, D. (2016). Emergent social identity and observing social support predict social support provided by survivors in a disaster: solidarity in the 2010 Chile earthquake. European Journal of Social Psychology, 46(2), 209-223. https://doi.org/10.1002/ejsp.2146

Drury, J., Stott, C., Ball, R., Neville, F., Bell, L., Biddlestone, M., Choudhury, S., Lovell, M., and Ryan, C. (2020). A social identity model of riot diffusion: from injustice to empowerment in the 2011 London riots. European Journal of Social Psychology, 50(3), 646-661. https://doi.org/10.1002/ejsp.2650

Fernandes-Jesus, M., Mao, G., Ntontis, E., Cocking, C., McTague, M., Schwarz, A., Semlyen, J., and Drury, J. (2021). More than a COVID-19 response: sustaining mutual aid groups during and beyond the pandemic. Frontiers in Psychology. https://doi.org/10.3389/fpsyg.2021.716202

Flesher Fominaya, C. (2011). The Madrid bombings and popular protest: misinformation, counterinformation, mobilisation and elections after '11-M'. Contemporary Social Science, 6(3), 289-307. https://doi.org/10.1080/21582041.2011.603910

Funabashi, Y., and Kitazawa, K. (2012). Fukushima in review: a complex disaster, a disastrous response. Bulletin of the Atomic Scientists, 68(2), 9-21. https://doi.org/10.1177/0096340212440359

Grant, P., and Smith, H. (2021). Activism in the time of COVID-19. Group Processes \& Intergroup Relations, 24(2), 297-305. https://doi.org/10.1177\%2F1368430220985208

Grimm, S., Lemay-Hérbert, N., and Nay, O. (2014). 'Fragile States': introducing a political concept. Third World Quarterly, 35(2), 197-209. https://doi.org/10.1080/01436597.2013.878127

Haugestad, C., Duun Skauge, A., Kunst, J., and Power, S. (2021). Why do youth participate in climate activism? A mixed-methods investigation of the \#FridaysForFuture climate protests. Journal of Environmental Psychology, 76. https://doi.org/10.1016/j.jenvp.2021.101647

Heldman, C. (2010). The truths of Katrina. https://drcarolineheldman.com/2010/08/25/thetruths-of-katrina/

Iacoella, F., Justino, P., and Martorano, B. (2021). Do pandemics lead to rebellion? Policy responses to COVID-19, inequality, and protests in the USA (WIDER Working Paper No. 2021/57). World Institute for Development Economics Research. https://www.wider.unu.edu/sites/default/files/Publications/Workingpaper/PDF/wp2021-57-pandemics-rebellion-policy-responses-COVID-19-inequalityprotests-USA.pdf 
Ide, T., Kristensen, A., and Bartusevičius, H. (2021). First comes the river, then comes the conflict? A qualitative comparative analysis of flood-related political unrest. Journal of Peace Research, 58(1), 83-97. https://doi.org/10.1177\%2F0022343320966783

Ikegami, Y. (2012). People's movement under the radioactive rain. Inter-Asia Cultural Studies, 13(1), 153-158. https://doi.org/10.1080/14649373.2012.639338

Kampmark, B. (2020). Protesting in pandemic times. Contention, 8(2), 1-20. https://doi.org/10.3167/cont.2020.080202

Kishi, R., and Jones, S. (2020). Demonstrations and political violence in America: New data for summer 2020. Armed Conflict Location and Event Data Project. https://acleddata.com/2020/09/03/demonstrations-political-violence-in-america-newdata-for-summer-2020/

Kishi, R., Pavlik, M., Bynum, E., Miller, A., Goos, C., Satre, J., and Jones, S. (2021). ACLED 2020: The year in review. Armed Conflict Location and Event Data Project. https://acleddata.com/2021/03/18/acled-2020-the-year-in-review/

Klandermans, B. (1984). Mobilization and participation: Social-psychological expansions of resource mobilization theory. American Sociological Review, 49(5), 583600. https://doi.org/10.2307/2095417

Kontominas, B. (2020, July 20). NSW police try to block Sydney Black Lives Matter protest in Supreme Court due to coronavirus concerns. ABC News.

https://www.abc.net.au/news/2020-07-20/nsw-police-to-block-sydney-black-livesmatter-protest-in-court/12474464

Koren, O., Bagozzi, B., and Benson, T. (2021). Food and water insecurity as causes of social unrest: evidence from geolocated Twitter data. Journal of Peace Research, 58(1), 67-82. https://doi.org/10.1177\%2F0022343320975091

Lange, M., and Monscheuer, O. (2021). Spreading the disease: protest in times of pandemics. ZEW Discussion paper, NO.21-009. https://ftp.zew.de/pub/zew-docs/dp/dp21009.pdf

Langton, M. (2020, August 5). Why the Black Lives Matter protests must continue: an urgent appeal by Marcia Langton. The Conversation. https://theconversation.com/why-theblack-lives-matter-protests-must-continue-an-urgent-appeal-by-marcia-langton-143914

Louis, W., Amiot, C., Thomas, E., and Blackwood, L. (2016). The "activist identity" and activism across domains: A multiple identities analysis. Journal of Social Issues, 72, 242-263. https://doi.org/10.1111/josi.12165

Luft, R. (2009). Beyond disaster exceptionalism: social movement developments in New Orleans after Hurricane Katrina. American Quarterly, 61(3), 499-527. https://www.jstor.org/stable/27735005

Marks, D., Connell, J., and Ferrara, F. (2020). Contested notions of disaster justice during the 2011 Bangkok floods: unequal risk, unrest and claims to the city. Asia Pacific Viewpoint, 61(1), 19-36. https://doi.org/10.1111/apv.12250 
Mao, G., Fernandes-Jesus, M., Ntontis, E., and Drury, J. (2021). What have we learned about COVID-19 volunteering in the UK? A rapid review of literature. BMC Public Health, 21, 1470. https://doi.org/10.1186/s12889-021-11390-8

Murphy, K., and Cherney, A. (2017). Policing marginalized groups in a diverse society: Using procedural justice to promote group belongingness and trust in police. In D. Oberwittler \& S. Roche (Eds.), Police-citizen relations across the world: Comparing sources and contexts of trust and legitimacy (pp. 153-174). Routledge.

Marks, D., Connell, J., and Ferrara, F. (2020). Contested notions of disaster justice during the 2011 Bangkok floods: unequal risk, unrest and claims to the city. Asia Pacific Viewpoint, 61(1), 19-36. https://doi.org/10.1111/apv.12250

Nardulli, P., Peyton, B., and Bajjalieh, J. (2015). Climate change and civil unrest: the impact of rapid-onset disasters. Journal of Conflict Resolution, 59(2), 310-335. https://doi.org/10.1177\%2F0022002713503809

NCAC. (2020, August 7). The right to protest during the pandemic. National Coalition Against Censorship. https://ncac.org/news/dissent-protest-pandemic

Nel, P., and Righarts, M. (2008). Natural disasters and the risk of violent civil conflict. International Studies Quarterly, 52, 159-185. https://www.jstor.org/stable/29734228

Neville, F., Templeton, A., Smith, J., and Louis, W. (2021). Social norms, social identities and the COVID-19 pandemic: Theory and recommendations. Social and Personality Psychology Compass, 15(5). e12596. https://doi.org/10.1111/spc3.12596

Ntontis, E., Drury, J., Amlôt, R., Rubin, J.G., and Williams, R. (2018). Emergent social identities in a flood: Implications for community psychosocial resilience. Journal of Community and Applied Social Psychology, 28(1), 3-14. https://doi:10.1002/casp.2329

Ntontis, E., Drury, J., Amlôt, R., Rubin, G.J., Williams, R. and Saavedra, P. (2020b), Collective resilience in the disaster recovery period: Emergent social identity and observed social support are associated with collective efficacy, well-being, and the provision of social support. British Journal of Social Psychology, 60(3), 10751095. https://doi.org/10.1111/bjso.12434

O'Sulllivan, M. (2020, April 20). Is protesting during the pandemic an 'essential' right that should be protected? The Conversation. https://theconversation.com/is-protestingduring-the-pandemic-an-essential-right-that-should-be-protected-136512

Ramsden, P. (2020, June 15). How the pandemic changed social media and George Floyd's death created a collective conscience. The Conversation.

https://theconversation.com/how-the-pandemic-changed-social-media-and-georgefloyds-death-created-a-collective-conscience-140104

Reicher, S. (1984). The St. Pauls' riot: an explanation of the limits of crowd action in terms of social identity model. European Journal of Social Psychology, 14(1), 1-21. https://doi.org/10.1002/ejsp.2420140102

Runciman, W. (1966). Relative deprivation and social justice: a study of attitudes to social inequality in twentieth-century England. University of California Press. 
Russo, T. (2020, June 4). How to protest during a pandemic and still keep everyone safe from coronavirus. The Conversation. https://theconversation.com/how-to-protest-during-apandemic-and-still-keep-everyone-safe-from-coronavirus-139978

Slettebak, R. (2013). Climate change, natural disasters, and post-disaster unrest in India. India Review, 12(4), 260-279. https://doi.org/10.1080/14736489.2013.846786

Solnit, R. (2009). A paradise built in hell: The extraordinary communities that arise in disaster. Penguin.

Stott, C., Radburn, M., Pearson, G., Kyprianides, A., Harrison, M., and Rowlands, D. (2021). Police powers and public assemblies: learning from the Clapham Common 'Vigil' during the Covid-19 pandemic. Policing: A journal of Policy and Practice, paab060. https://doi.org/10.1093/police/paab060

Subašić, E., Reynolds, K., and Turner, J. (2008). The political solidarity model of social change: dynamics of self-categorization in intergroup power relations. Personality and Social Psychology Review, 12(4), 330-352. https://doi.org/10.1177\%2F1088868308323223

Tekin Güven, S. and Drury, J. (2020). How do those affected by a disaster organize to meet their needs for justice? Campaign strategies and partial victories following the Grenfell Tower fire. SocArXiv. DOI: https://doi.org/10.31235/osf.io/xrcfq

Tekin Güven, S., and Drury J. (2021). Silent walk as a street mobilization: campaigning following the Grenfell Tower fire. Journal of Community \& Applied Social Psychology, 31(4), 425-437. https://doi.org/10.1002/casp.2521

Tajfel, H., and Turner, J. (1979). An integrative theory of intergroup conflict. In W. G. Austin and S. Worchel (Eds.), The social psychology of intergroup relations (pp. 3348). Brooks/Cole.

Tavan, L. (2020, July 3). Who's to blame for Victoria's COVID-19 spike? Redflag - a publication of socialist alternative. https://redflag.org.au/node/7252

Templeton, A., Tekin Guven, S., Hoerst, C., Vestergren, S., Davidson, L., Ballentyne, S., Madsen, H., and Choudhry, S. (2020). Inequalities and identity processes in crises: recommendations for facilitating safe response to the COVID-19 pandemic. British Journal of Social Psychology, 59 (3), 674-685. https://doi.org/10.1111/bjso.12400

Tierney, K., Bevc, C., and Kuligowski, E. (2006). Metaphors matter: Disaster myths, media frames, and their consequences in Hurricane Katrina. The Annals of the American Academy of Political and Social Science, 604(1), 57-81. https://doi.org/10.1177\%2F0002716205285589

van Zomeren, M., Spears, R., Fisher, A., and Leach, C. (2004). Put your money where your mouth is! Explaining collective action tendencies through group-based anger and group efficacy. Journal of Persoanlity ans Social Psychology, 87(5), 649-664. https://doi.apa.org/doi/10.1037/0022-3514.87.5.649

Van Zomeren, M., Postmes, T., and Spears, R. (2008). Toward an integrative social identity model of collective action: A quantitative research synthesis of three socio- 
psychological perspectives. Psychological Bulletin, 134, 504-535.

https://doi.apa.org/doi/10.1037/0033-2909.134.4.504

Vestergren, S., Drury, J., and Hammar Chiriac, E. (2019). How participation on collective action changes relationships, behaviours, and beliefs: an interview study of the role of inter- and intragroup processes. Journal of Social and Political Psychology, 7 (1), 7699. https://doi.org/10.5964/jspp.v7i1.903

Walker, I., and Smith, H. J. (Eds.). (2002). Relative deprivation: Specification, development, and integration. Cambridge University Press.

Williams, M. S. (1998). Voice, trust, and memory: Marginalized groups and the failings of liberal representation. Princeton University Press. 